DOI: $10.5277 /$ epe 160312

\title{
THE ENVIRONMENTAL POLLUTION WITH COPPER AND ZINC ALONG THE COMMUNICATION ROUTES IN WROCŁAW, POLAND
}

\begin{abstract}
Copper and zinc concentrations in soils and grasses near selected communication routes in Wrocław, Poland have been determined. Environmental samples were collected from the surface layer of the soil profile within $3 \mathrm{~m}$ from the edge of the road. The analysis of metals in the mineralizates has been carried out by atomic absorptive spectroscopy (AAS). The conductivity and $\mathrm{pH}$ of the soil solutions were measured to evaluate the salinity of the soils and also their active and exchangeable acidity. There have been determined the parameters characterizing the content of metals in soils and grasses, the index of the enrichment of soils in zinc and copper $(W n)$, the bioaccumulation coefficient $(W B)$, histograms of the frequency of metals occurrence in environmental samples. Also it was presented the Pearson's $r$ correlation coefficients for the relationships: $\mathrm{Zn}$ in soil/ $\mathrm{Cu}$ in soil, $\mathrm{Zn}$ in grass/Cu in grass, $\mathrm{Cu}$ in grass/Cu in soil, $\mathrm{Zn}$ in grass/Zn in soil. The research does not indicate exceeding of the permissible content of copper and zinc in the environment. However, in all samples higher content of the metals compared to the geochemical background have been observed.
\end{abstract}

\section{INTRODUCTION}

Urbanized regions and the areas adjacent to communication routes are the most likely to be affected by the traffic. The architecture of densely populated areas often limits the natural exchange of air. The sources of heavy metals are exhaust fumes from engines, various types of grease used in cars and tires which rub away during exploitation. Zinc finds in the tires, copper originates from the engines, parts of the braking system and the corrosion of engine coolers. Some substances might deposit on the surface of the road, while other occur in a certain distance from the road. Heavy metals are accumulated in the soil in the nearest areas of the communication routes. Their content depends on intensity of traffic on the road, and it typically decreases along the increase

${ }^{1}$ Faculty of Environmental Engineering, Wrocław University of Science and Technology, Wybrzeże Wyspiańskiego 27, 50-370 Wrocław, Poland, corresponding author A. Hołtra, e-mail: anna.holtra@pwr.edu.pl 
of the distance from the edge of the road [1-4]. The falling of the metalliferous dust depends also on the local meteorological conditions such as the wind direction and the aerodynamic surface roughness (the shape of the surface, occurrence of natural barriers such as afforestation of the area) [5]. Wet and dry deposition fosters the accumulation of metals in the soils and their inclusion in the food chain, creating a hazard for all trophic levels. The corollary of the contamination of the soil environment by the traffic is the increased acidification of the soil and the increased solubility of the complexes of the heavy metals with sorbents. In the soils with neutral and alkaline $\mathrm{pH}$, the movement of metals to the deeper layers of the soil profile is limited. $\mathrm{pH}<7$ of the soil fosters the movement of metals and their phytoassimilation [5-8]. A local metalliferous dust contamination may originate from industrial plants and heating devices (boilers, incinerators) [5].

Poland is a country in which significant contamination of soils with metals have not been observed. The research conducted until 2010 by the Institute of Soil Science and Plant Cultivation in Puławy and also by the National Inspectorate of Environmental Protection have proven that within the Polish territory the soils with zero contamination with lead, cadmium, nickel, copper and zinc are dominant. Such areas constituted ca. $90 \%$ of the country's territory. Around $10 \%$ of the area of Poland has been affected by the level one contamination, while level two or higher has affected less than $2 \%$ of the territory. The above figures indicate that the overall state of the Polish soils is good. The increased values of metallic contamination occur locally and relate mainly to industrial areas and regions which underwent significant anthropopression influences. In selected areas in the vicinity of the source of the emission of contaminants, the soils sometimes show significant levels of contamination [9-11]. In 2014, in Lower Silesia the research was carried out in only one district of Polkowice. Exceeded permissible concentrations were observed for zinc, lead, copper, chromium and arsenic. There were no exceedances of the concentration limits of cadmium, nickel and mercury [12].

The copper contamination of soils is observed in many cities. In urban soils of Warsaw contamination of $17 \mathrm{mg} \mathrm{Cu} / \mathrm{kg}$ of dry matter has been recorded, in Cracow $-14 \mathrm{mg} \mathrm{Cu} / \mathrm{kg}$ of dry matter, in Wrocław $-27 \mathrm{mg} \mathrm{Cu} / \mathrm{kg}$ of dry matter, in Szczecin $-10 \mathrm{mg} \mathrm{Cu} / \mathrm{kg}$ of dry matter. The geochemical background of copper in uncontaminated soils of Poland is estimated at the level of 10-50 mg Cu/kg of dry matter. The average content of zinc in urban soils in Gdańsk amounts to $73 \mathrm{mg} \mathrm{Zn/kg}$ of dry matter, in Wrocław - $132 \mathrm{mg} \mathrm{Zn/kg}$ of dry matter, in Łódź - $46 \mathrm{mg} \mathrm{Zn/kg} \mathrm{of} \mathrm{dry} \mathrm{matter,} \mathrm{in} \mathrm{Warsaw} \mathrm{-} 298 \mathrm{mg} \mathrm{Zn/kg} \mathrm{of} \mathrm{dry} \mathrm{matter.} \mathrm{The}$ geochemical background of zinc in uncontaminated soils of Poland is estimated at the level of $30-40 \mathrm{mg} \mathrm{Zn} / \mathrm{kg}$ of dry matter. Metal concentration recorded in the soils of municipal parks amounts 5-27 mg Cu/kg of dry matter and $31-125 \mathrm{mg} \mathrm{Zn} / \mathrm{kg}$ of dry matter, while in lawns the concentration of copper ranges from 2 to $45 \mathrm{mg} / \mathrm{kg}$ of dry matter [13, 14].

The assessment of quality of the soils is carried out based on the degree of contamination with heavy metals $(\mathrm{Pb}, \mathrm{Zn}, \mathrm{Cu}, \mathrm{Ni}, \mathrm{Cd}, \mathrm{Cr})$. In the surface layer of the soil, $(0-20 \mathrm{~cm})$ the threshold limit value of copper and zinc, corresponding to the zero level 
of contamination (the natural content), for light, medium and heavy soil, equals: 15, 25, $40 \mathrm{mg} \mathrm{Cu} / \mathrm{kg}$ of dry matter and 50, $70 \mathrm{i} 100 \mathrm{mg} \mathrm{Zn/kg}$ of dry matter, respectively [15].

The permissible content of copper and zinc in the soil layer from 0 to $30 \mathrm{~cm}$ deep for type B soils which include, among others, urbanized and built-up regions excluding industrial, mining and traffic areas, equals 150 and $300 \mathrm{mg} / \mathrm{kg}$ of dry matter, respectively [16]. The concentrations of copper and zinc in the soils and grasses in the direct vicinity of roads may demonstrate the influence of intensity of traffic on the environment in Wrocław, when in the immediate surroundings of the investigated roads there are no industrial plants.

\section{MATERIALS AND METHODS}

The samples have been collected within 3 meter distance from the edge of the road, with 21 locations as shown in Table 1, in the spring-autumn periods from 2012 to 2014.

Table 1

Physicochemical parameters of soils

\begin{tabular}{|c|c|c|c|c|c|}
\hline Location & $\begin{array}{c}\text { Point of sample collection } \\
\text { (ca. } 3 \mathrm{~m} \text { from the edge of the road) }\end{array}$ & Symbol & $\begin{array}{c}\mathrm{pH} \\
1 \mathrm{M} \mathrm{KCl}\end{array}$ & $\begin{array}{c}\mathrm{pH} \\
\mathrm{H}_{2} \mathrm{O}\end{array}$ & $\begin{array}{c}\mathrm{EC} \\
{[\mathrm{mS} / \mathrm{cm}]}\end{array}$ \\
\hline \multirow{3}{*}{$\begin{array}{l}\text { Communication route along } \\
\text { Grunwaldzki Square }\end{array}$} & Orlen petrol station & $\mathrm{O}$ & 7.10 & 7.65 & 0.63 \\
\hline & Reagan roundabout & $\mathrm{R}$ & 7.13 & 7.77 & 0.42 \\
\hline & Wyspiański Coast intersection & $\mathrm{W}$ & 7.40 & 7.87 & 0.41 \\
\hline \multirow{6}{*}{$\begin{array}{l}\text { Communication route along } \\
\text { Stanisław Wyspiański Coast }\end{array}$} & $\begin{array}{l}\text { University of Science and Technology } \\
\text { H4 building }\end{array}$ & $\mathrm{H} 4$ & 7.08 & 7.72 & 0.21 \\
\hline & $\begin{array}{l}\text { University of Science and Technology } \\
\text { C13 building (Polinka station) }\end{array}$ & $\mathrm{C} 13$ & 6.48 & 6.96 & 0.24 \\
\hline & $\begin{array}{l}\text { University of Science and Technology } \\
\text { A1 building }\end{array}$ & A1 & 7.25 & 7.71 & 0.25 \\
\hline & $\begin{array}{l}\text { University of Science and Technology } \\
\text { canteen building }\end{array}$ & S1 & 6.85 & 7.23 & 0.17 \\
\hline & M. Smoluchowskiego intersection & S2 & 6.52 & 7.01 & 0.14 \\
\hline & Zwierzyniecki Bridge & $\mathrm{MZ}$ & 7.09 & 7.38 & 0.18 \\
\hline \multirow{3}{*}{$\begin{array}{l}\text { Communication route along } \\
\text { Ignacy Łukasiewicz Street }\end{array}$} & \multirow{3}{*}{ Park } & $\mathrm{P} 1$ & 4.98 & 5.67 & 0.29 \\
\hline & & $\mathrm{P} 2$ & 5.59 & 6.38 & 0.21 \\
\hline & & P3 & 4.44 & 4.48 & 0.39 \\
\hline \multirow{3}{*}{$\begin{array}{l}\text { Communication route along } \\
\text { Zygmunt Wróblewski Street }\end{array}$} & Wystawowa Street intersection & WR1 & 4.48 & 4.99 & 0.34 \\
\hline & Centennial Hall & WR2 & 5.15 & 6.06 & 0.18 \\
\hline & Kopernik Street intersection & WR3 & 4.23 & 5.17 & 0.09 \\
\hline \multirow{3}{*}{$\begin{array}{l}\text { Communication route along } \\
\text { Mikołaj Kopernik Street }\end{array}$} & Kochanowski Street intersection & MK1 & 6.55 & 6.94 & 0.11 \\
\hline & Dickstein Street intersection & MK2 & 5.02 & 5.94 & 0.11 \\
\hline & Banach Street intersection & MK3 & 4.96 & 5.89 & 0.15 \\
\hline \multirow{3}{*}{$\begin{array}{l}\text { Communication route along } \\
\text { Adam Mickiewicz Street }\end{array}$} & Japanese Garden & AM1 & 5.83 & 6.56 & 0.14 \\
\hline & Wystawowa Street intersection & AM2 & 6.17 & 6.69 & 0.15 \\
\hline & Zwierzyniecki Bridge & AM3 & 5.37 & 6.20 & 0.13 \\
\hline
\end{tabular}


The soils came from the surface layer of the soil profile $(20 \mathrm{~cm}$ deep). The soil samples about $500 \mathrm{~g}$ and the grass samples about $200 \mathrm{~g}$ (with a plant root system) were taken. The soil sample to be analyzed was the average of three samples taken from each location. For the average and properly prepared samples (grinding, sieving and drying), the measurement of the physicochemical parameters $(\mathrm{pH}$ in water and $1 \mathrm{M} \mathrm{KCl}$ and electrical conductivity, EC) were made [PN-ISO 10390:1997].

Samples used for the mineralization process were dried in order to reach the absolute dry matter [PN-ISO 11465:1999]. In the process of microwave mineralization with the use of Start D device (Milestone), mineralizates in the $65 \%$ solution of nitric $(\mathrm{V})$ acid supra pure have been obtained. In every series of mineralizates, a control procedure has been carried out (blind study). The designation of the metals concentration in solutions was conducted in minimum six repetitions by the atomic absorption spectroscopy method (AAS) with the use of flame technique of iCE 3500 Solaar device (Thermo Scientific) [PN-ISO 11047:2001]. The results underwent statistical analysis during which the average contents of metals and standard deviations were calculated.

Chemical analyses have been carried out in the certified Laboratory of Toxicology and Environmental Research in the Faculty of Environmental Engineering at the Wrocław University of Science and Technology.

Statistical calculations (arithmetic mean, standard deviation, minimum and maximum values, median, lower quartile and upper quartile, volatility index, skewness, kurtosis) have been carried out using the Microsoft Excel software. The accumulation indexes $(W n)$ of $\mathrm{Zn}$ and $\mathrm{Cu}$ in soils were calculated as the ratio of the average content of a given element in the contaminated soil versus the geochemical background, which is $30.0 \mathrm{mg} \mathrm{Zn} / \mathrm{kg}$ of dry matter and $5.0 \mathrm{mg} \mathrm{Cu} / \mathrm{kg}$ of dry matter. The bioaccumulation coefficients $(W B)$ of metals in the grasses were calculated as the ratio of element concentration in a plant to the metal concentration in the soil.

\section{RESULTS AND DISCUSSION}

The bioavailability of metals for plants is mostly determined by the physicochemical properties of soil. $\mathrm{pH}$ measured in $1 \mathrm{M} \mathrm{KCl}$ solution (exchangeable acidity) for all investigated samples estimated between 4.23 and 7.40 (Table 1), while the average arithmetic mean is 5.98. As expected, active acidity in soil solutions ( $\mathrm{pH}$ in water) is higher than the $\mathrm{pH}$ in $\mathrm{KCl}$, and the difference between the values does not exceed 1.0 unit.

In three measurement points, highly acidic reaction of soils has been recorded (exchangeable acidity in $1 \mathrm{M} \mathrm{KCl}$ ), in five measurement points - acidic reaction, in four measurement points - slightly acidic reaction, in seven measurement points - neutral reaction, while in two measurement points base reaction occurred (Table 1). The share of samples collected from the acidic and highly acidic soils amounted to $57 \%$. Soils 
with low $\mathrm{pH}$ may pose a threat to the environment because of the mobility of metallic elements and the increase of their share in the biogeochemical circulation. The binding of most of heavy metals increases substantially in solutions close to neutral and such soils are described as immune to chemical contamination. Due to high $\mathrm{pH}$ values of soils in nine measurement points (neutral and alkaline character of the soils), $\mathrm{pH}$ was not a factor influencing the increased movement of metals in the investigated samples. It suggests a low level of the movement of metals deep into the soil profile. Urban soils typically demonstrate higher $\mathrm{pH}$ values - this fact was already recorded by several authors and can be partly explained by the occurrence of building materials such as bricks and rubble which can increase $\mathrm{pH}$ of soils [2]. Additionally, the soil samples have been collected by the edge of the road, therefore from areas which have not been enriched with nutrients.

Conductivity of soil solutions is low, below $0.25 \mathrm{mS} / \mathrm{cm}$ for $71 \%$ of soil samples (low salinity). Conductivity of remaining soil solutions does not exceed $0.75 \mathrm{mS} / \mathrm{cm}$, thus these soils can be considered as having medium salinity (Table 1).

Table 2

The content of $\mathrm{Zn}$ and $\mathrm{Cu}$ in soils and grasses along communications routes [mg/kg]

\begin{tabular}{|c|c|c|c|c|c|c|c|c|c|c|}
\hline \multirow{3}{*}{ Location } & \multicolumn{6}{|c|}{ Soil } & \multicolumn{4}{|c|}{ Grass } \\
\hline & \multicolumn{3}{|c|}{$\mathrm{Zn}$} & \multicolumn{3}{|c|}{$\mathrm{Cu}$} & \multicolumn{2}{|c|}{$\mathrm{Zn}$} & \multicolumn{2}{|c|}{$\mathrm{Cu}$} \\
\hline & $x$ & STZ & $s$ & $x$ & STZ & $s$ & $x$ & $s$ & $x$ & $s$ \\
\hline $\mathrm{O}$ & 295.76 & II & 0.17 & 62.28 & II & 0.12 & - & - & - & - \\
\hline $\mathrm{R}$ & 77.10 & I & 1.70 & 40.60 & I & 3.00 & 79.70 & 2.40 & 27.42 & 0.70 \\
\hline $\mathrm{W}$ & 113.60 & I & 5.50 & 36.00 & I & 3.00 & 89.90 & 2.20 & 21.62 & 0.30 \\
\hline $\mathrm{H} 4$ & 188.80 & I & 1.00 & 37.60 & I & 0.22 & 99.93 & 0.50 & 15.27 & 0.32 \\
\hline $\mathrm{C} 13$ & 232.96 & II & 0.58 & 55.47 & II & 0.43 & - & - & - & - \\
\hline A1 & 197.25 & $\mathrm{I}$ & 0.89 & 39.80 & $\mathrm{I}$ & 0.15 & 83.10 & 0.43 & 10.84 & 0.14 \\
\hline S1 & 121.59 & $\mathrm{I}$ & 0.51 & 26.81 & $\mathrm{I}$ & 0.18 & 50.45 & 0.21 & 8.92 & 0.25 \\
\hline S2 & 147.71 & $\mathrm{I}$ & 0.41 & 57.32 & II & 0.43 & 116.99 & 0.37 & 14.98 & 0.17 \\
\hline $\mathrm{P} 1$ & 143.95 & $\mathrm{I}$ & 0.74 & 35.44 & I & 0.09 & - & - & - & - \\
\hline $\mathrm{P} 2$ & 136.87 & $\mathrm{I}$ & 0.56 & 30.41 & $\mathrm{I}$ & 0.13 & 152.99 & 0.40 & 19.59 & 0.15 \\
\hline $\mathrm{P} 3$ & 116.26 & $\mathrm{I}$ & 0.42 & 30.78 & $\mathrm{I}$ & 0.15 & 110.25 & 0.33 & 14.85 & 0.30 \\
\hline $\mathrm{MZ}$ & 187.47 & I & 0.41 & 41.83 & I & 0.27 & 62.81 & 0.11 & 10.33 & 0.23 \\
\hline WR1 & 121.18 & $\mathrm{I}$ & 0.64 & 49.96 & $\mathrm{I}$ & 0.24 & - & - & - & - \\
\hline WR2 & 229.40 & II & 0.39 & 63.65 & II & 0.29 & 175.50 & 1.20 & 19.20 & 0.21 \\
\hline WR3 & 85.85 & $\mathrm{I}$ & 0.45 & 73.24 & II & 0.50 & 222.00 & 2.70 & 44.97 & 0.26 \\
\hline MK1 & 126.54 & $\mathrm{I}$ & 0.45 & 26.47 & $\mathrm{I}$ & 0.22 & - & - & - & - \\
\hline MK2 & 128.43 & I & 0.45 & 21.85 & 0 & 0.11 & - & - & - & - \\
\hline MK3 & 109.22 & $\mathrm{I}$ & 0.20 & 27.69 & $\mathrm{I}$ & 0.16 & - & - & - & - \\
\hline AM1 & 210.30 & II & 0.57 & 85.13 & III & 0.25 & - & - & - & - \\
\hline AM2 & 182.39 & I & 0.43 & 59.50 & II & 0.13 & - & - & - & - \\
\hline AM3 & 218.47 & II & 0.97 & 89.68 & III & 0.17 & - & - & - & - \\
\hline
\end{tabular}

$x$ - arithmetic mean, $\mathrm{s}$ - standard deviation for minimum 6 measurements; STZ - degree of soil contamination [15]. 
The content of $\mathrm{Zn}$ and $\mathrm{Cu}$ in the investigated samples of soils and grasses is characterized by considerable diversity, which is typical of urban soils [17]. The average concentrations of metals for individual locations $(\times)$ are presented in Table 2 . The content of zinc in soils ranged from 77.10 (location R) to $295.76 \mathrm{mg} \mathrm{Zn/kg}$ of dry matter (location O), whereas the content of copper ranged from 21.85 (location MK2) to 89.68 $\mathrm{mg} \mathrm{Cu} / \mathrm{kg}$ of dry matter (location AM3). In grasses, concentrations of metals ranged from 50.45 (location S1) to $220.00 \mathrm{mg} \mathrm{Zn/kg}$ of dry matter (location WR3), whereas the content of copper ranged from 8.92 (location S1) to $44.97 \mathrm{mg} \mathrm{Cu} / \mathrm{kg}$ of dry matter (location WR3). The concentrations of zinc in both kinds of samples, soils and grasses, were higher than the concentrations of copper in the respective measurement points. The highest recorded concentration of metals in urban soils according to Kabata-Pendias and Pendias [18] for zinc are 4.7 times higher and for copper 3.5 times higher than the content of these metals in uncontaminated soils, being $17-125 \mathrm{mg} \mathrm{Zn} / \mathrm{kg}$ of dry matter and $6-60 \mathrm{mg} \mathrm{Cu} / \mathrm{kg}$ of dry matter.

The standard for type B soils [16] for zinc and copper equals, $300 \mathrm{mg} \mathrm{Zn/kg}$ of dry matter and $150 \mathrm{mg} \mathrm{Cu} / \mathrm{kg}$ of dry matter, respectively, and was not exceeded in any of the investigated samples (Table 2). The assessment of the results by available methods $[15,19]$ allows the determination of degrees of the contamination of soils with heavy metals (STZ).

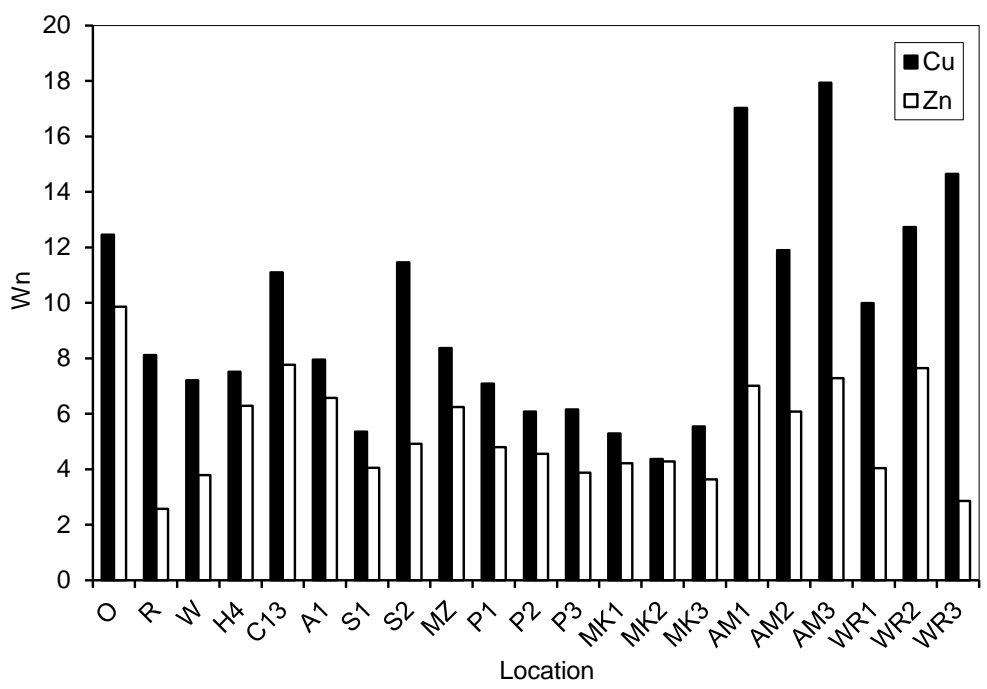

Fig. 1. The accumulation indexes $(W n)$ of $\mathrm{Zn}$ and $\mathrm{Cu}$ in soils

In the case of zinc and copper, the threshold limit values in the surface layer of the soil for the first degree equaled (elevated content) $200 \mathrm{mg} \mathrm{Zn/kg}$ and $50 \mathrm{mg} \mathrm{Cu} / \mathrm{kg}$ of dry matter, respectively, For the second degree (low contamination) they amounted to $500 \mathrm{mg} \mathrm{Zn} / \mathrm{kg}$ and $80 \mathrm{mg} \mathrm{Cu} / \mathrm{kg}$ of dry matter. In the case of zinc $76 \%$ of soil samples 
were characterized by elevated content (1st degree), whereas $24 \%$ were slightly contaminated (2nd degree). While the 1st degree of copper contamination was demonstrated by $57 \%$ of samples and $38 \%$ of samples were influenced by the 2 nd degree of contamination. 3rd degree, i.e. medium contamination (up to $100 \mathrm{mg} \mathrm{Cu} / \mathrm{kg}$ of dry matter) was recorded only in one of the soil samples. In all soil samples (Table 2) higher content of $\mathrm{Zn}$ and $\mathrm{Cu}$ compared to the geochemical background estimated at the level of 30 and $5 \mathrm{mg} / \mathrm{kg}$ of dry matter was observed [20].

The enrichment of the surface layers of soils with $\mathrm{Zn}$ and $\mathrm{Cu}$ as compared to the natural level of bedrock (Fig. 1) equals on average 5.22 for zinc (minimum 2.57, maximum 9.86) and 9.44 for copper (minimum 4.37, maximum 17.94). The accumulation indices $(W n)$ for copper are higher than those for zinc in the soil samples. In soils located near the steelworks in Nowa Huta, the values of $W n$ for zinc ranged from 4.8 to 2.5 depending on the distance between the measurement point and the steelworks [5]. The zinc accumulation index in soils adjacent to a petrol station in Cracow ranged from 1.70 to 14.11, whereas for copper it ranged from 2.05 to 16.53 . The enrichment of the surface layers of soils with metals as compared to the natural level of bedrock equaled $557 \%$ for zinc and $472 \%$ for copper [8]. The degree of enrichment of soils in floodplains in Opole along Odra river ranged from 1.2 to 26.0 for zinc and 1.3 to 7.3 for copper [21].

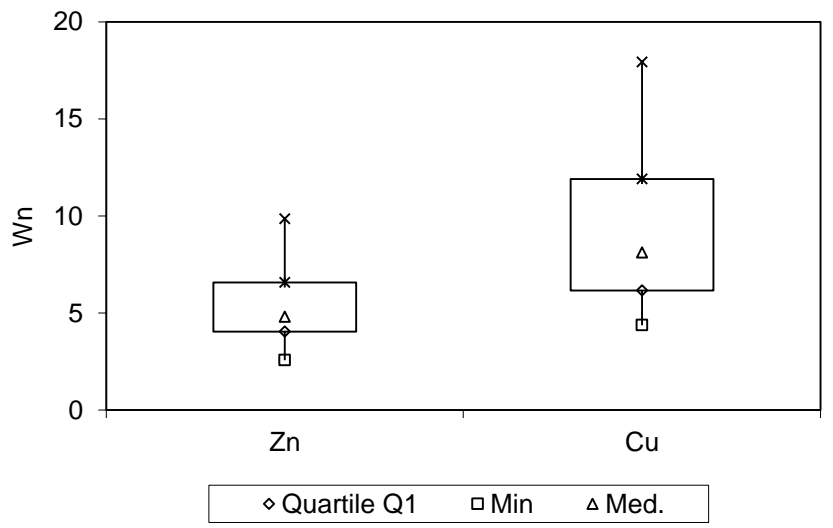

Fig. 2. The accumulation indexes $(W n)$ of $\mathrm{Zn}$ and $\mathrm{Cu}$ in soils compared to the geochemical background

$W n$ as an average for all soil samples has been presented in Fig. 2. The median of the degree of soil enrichment with zinc amounts to $4.80 \mathrm{mg} / \mathrm{kg}$ of dry matter (minimum 2.57 , maximum 9.86) and for copper $-8.12 \mathrm{mg} / \mathrm{kg}$ of dry matter (minimum 4.37 , maximum 17.94).

The median for the content of zinc in soils equals $137.62 \mathrm{mg} / \mathrm{kg}$ of dry matter and the volatility index is $36 \%$ (Table 3, Fig. 3). In grasses, the median equals $91.92 \mathrm{mg} / \mathrm{kg}$ of dry matter with the same volatility index $-36 \%$. For copper, the median equals 40.12 
$\mathrm{mg} / \mathrm{kg}$ of dry matter, the volatility index $40 \%$, whereas in grasses the median equals $15.22 \mathrm{mg} \mathrm{Cu} / \mathrm{kg}$ of dry matter with the volatility index of $34 \%$. The volatility index indicates low diversity of $\mathrm{Zn}$ and $\mathrm{Cu}$ contents in the surface layers of soils and in grasses (Table 3).

Table 3

Parameters characterizing the content of metals in soils and grasses

\begin{tabular}{|l|c|c|c|c|}
\hline \multirow{2}{*}{ Parameter } & \multicolumn{2}{|c|}{ Soils } & \multicolumn{2}{c|}{ Grasses } \\
\cline { 2 - 5 } & $\mathrm{Zn}$ & $\mathrm{Cu}$ & $\mathrm{Zn}$ & $\mathrm{Cu}$ \\
\hline Number of samples, $n$ & 115 & 133 & 52 & 60 \\
\hline Minimum, $x_{\min }, \mathrm{mg} / \mathrm{kg}$ & 73.34 & 21.71 & 50.12 & 8.61 \\
\hline Maximum, $x_{\max }, \mathrm{mg} / \mathrm{kg}$ & 295.96 & 89.97 & 176.57 & 28.71 \\
\hline Arithmetic mean, $x, \mathrm{mg} / \mathrm{kg}$ & 156.61 & 46.88 & 101.50 & 16.28 \\
\hline Standard deviation, $\mathrm{s}$ & 56.20 & 18.80 & 36.56 & 5.50 \\
\hline Median, Med., $\mathrm{mg} / \mathrm{kg}$ & 137.62 & 40.12 & 91.92 & 15.22 \\
\hline Volatility index, $V=(s / x) \times 100, \%$ & 36 & 40 & 36 & 34 \\
\hline Number of exceedings of the standard for soils of type B & 0 & 0 & - & - \\
\hline The standard for soils of type B & 300 & 150 & - & - \\
\hline
\end{tabular}

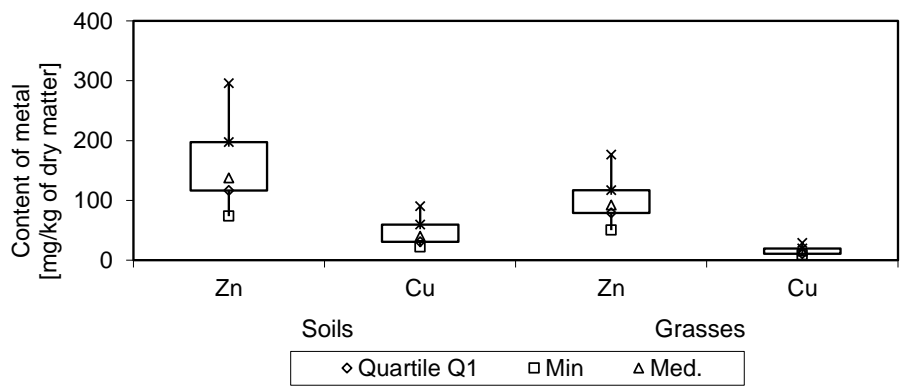

Fig. 3. The content of $\mathrm{Zn}$ and $\mathrm{Cu}$ in the surface layer of soils and in grasses

The bioaccumulation coefficients (WB) of metals range from 0.34 to 1.12 (median 0.78 ) for zinc and from 0.25 to 0.68 (median 0.37) for copper (Fig. 4). The values of copper and zinc bioaccumulation coefficients show that the elements easily accumulate in plant tissues and enter into the trophic chain. The degree of metal accumulation in grasses equals on average 0.71 for zinc and 0.42 for copper. The bioaccumulation coefficient in grasses near a petrol station in Cracow according to Baran et al. [8] ranged from 0.14 to 0.76 for zinc and from 0.07 to 0.83 for copper. These values indicate medium degree of copper and zinc accumulation in grasses, which proves high mobility of these metals and the ease with which they are collected by plants. Kaszubkiewicz and Kawałko [9] point out that in grains the most accumulated element was zinc (median of 
approx. 0.5) and copper was accumulated to lesser extent (about 0.2). In straw, the median of the bioaccumulation coefficient equaled 0.2 for zinc and 0.1 for copper, whereas in grass the value of median amounted to 0.5 for zinc and above 0.2 for copper.

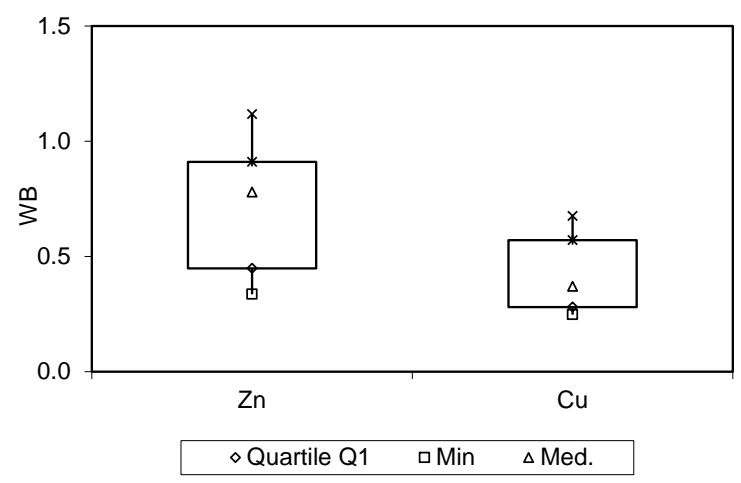

Fig. 4. The bioaccumulation coefficients $(W B)$ of metals in grasses

The contamination of grass with metals can be compared with threshold content of the elements in fodder plants. According to Kabata-Pendias et al. [15]. it is assumed that the fodder from grassland should contain from 50 to $100 \mathrm{mg} \mathrm{Zn/kg} \mathrm{of} \mathrm{dry} \mathrm{matter} \mathrm{and}$ from 7.1 to $10 \mathrm{mg} \mathrm{Cu} / \mathrm{kg}$ of dry matter. The number of samples in which exceeding of these values was recorded equaled $42 \%$ for zinc and $90 \%$ for copper. The maximum recorded multiplicity of the exceeding amounted to 1.8 for zinc and 2.9 for copper, which corresponds to $176.57 \mathrm{mg} \mathrm{Zn} / \mathrm{kg}$ and $28.71 \mathrm{mg} \mathrm{Cu} / \mathrm{kg}$. Minimum concentrations of metals in grass samples amounted to $50.12 \mathrm{mg} \mathrm{Zn/kg} \mathrm{of} \mathrm{dry} \mathrm{matter} \mathrm{and} 8.61 \mathrm{mg} \mathrm{Cu} / \mathrm{kg}$ of dry matter, respectively.

Comparison of histograms of the frequency of occurrence of zinc and copper in soils (Figs. 5a, 5c) and grasses samples (Figs. 5b, 5d) reveals deviations from the bell curve caused by substantial diversification of zinc and copper content in the population of investigated environmental samples. One of the reasons for that are different locations of sample collection in the city and diversified intensity of traffic. Histograms are right-skewed, which means that there are more results with concentrations lower than the average value. Kurtosis (below zero) confirms that there are few results close to arithmetic mean (many extreme results). The asymmetry index (skewness) of the histograms of the content of zinc in soils and grasses equals 0.60 (Fig. 5a) and 0.70 (Fig. 5b), respectively, whereas for copper it amounted to 0.77 (Fig. 5c) and 0.53 (Fig. 5d), respectively. Skewness for the same metals in soils of the allotment gardens in Wrocław amounted to 3.8 for zinc and 4.3 for copper [6]. Biasioli et al. [2] recorded the following values of the skewness index: 1.34 for zinc in urban soils (city of Torino, Italy) and 1.66 for zinc in rural soils and for copper 1.86 and 1.84, respectively. 

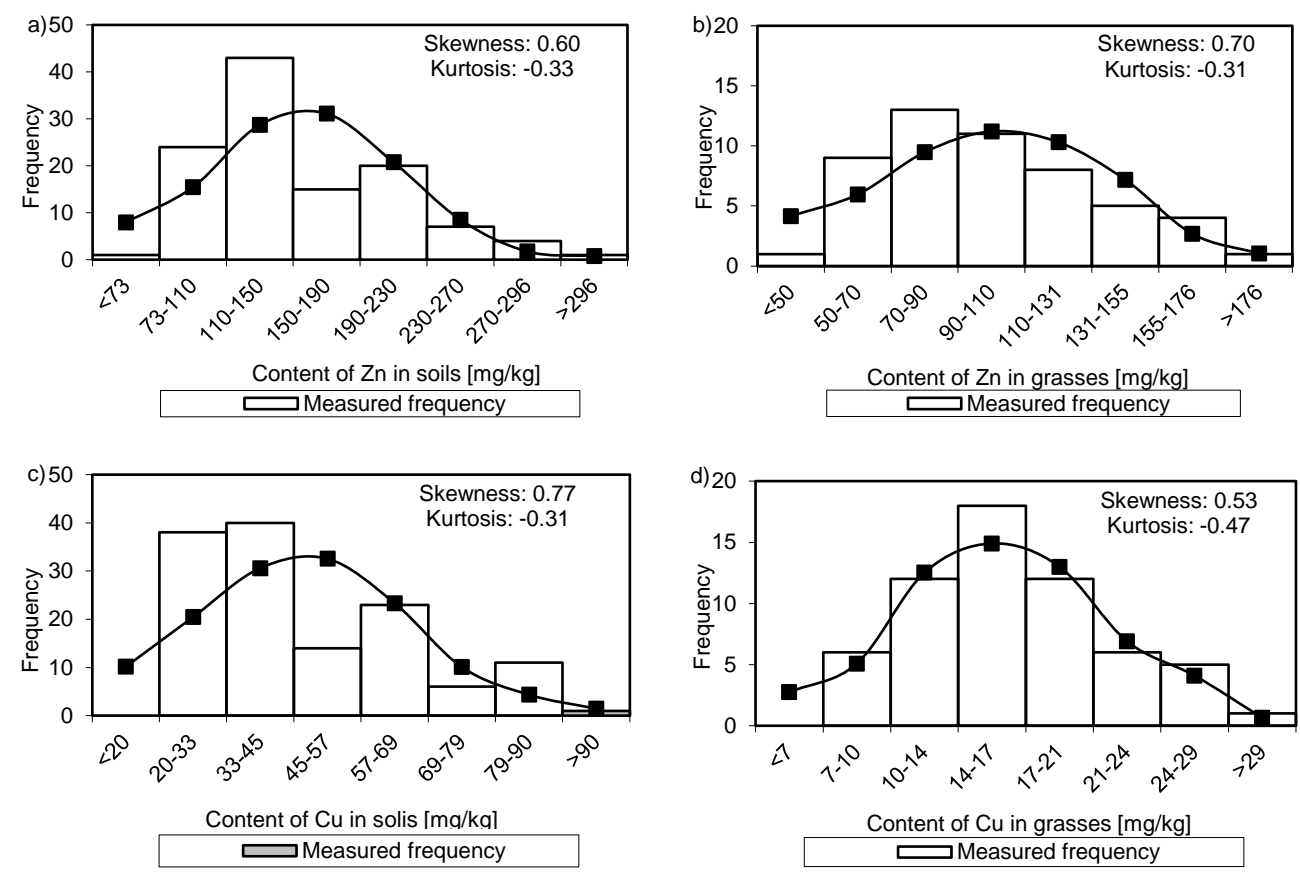

Fig. 5. Histograms of the frequency of occurrence in environmental samples: $\mathrm{Zn}$ in soils (a) and grasses (b), $\mathrm{Cu}$ in soils (c) and grasses (d)

Dependences of $\mathrm{Zn}$ contents on $\mathrm{Cu}$ contents in soils and grasses (Fig. 6) of metal contents in grasses on metal contents in soils (Fig. 7) for $\mathrm{Zn}$ and $\mathrm{Cu}$ may be described with a linear mathematical model. Slopes of the regression lines are positive in all cases. The intercepts of the linear regression equations significantly differ in values. The linear dependence of the concentration of $\mathrm{Zn}$ on that of $\mathrm{Cu}$ in plant tissues and the concentration of this metal in soil is characteristic of the indicator plants (bioindicators). The content of metal in plant may reflect its content in soil, however this relationship may vary depending on the species of plant and the type of tissue. According to Kabata-Pendias and Pendias [18], the concentrations of zinc and copper in Taraxacum officinale (dandelion) exceed the levels of these metals in other plant species. In Poland, samples of dandelion collected with the distance ranging from 0.5 to $2.5 \mathrm{~km}$ from the ironworks contained from 73 to $274 \mathrm{mg} \mathrm{Cu} / \mathrm{kg}$ of dry matter in leaves and from 22 to $199 \mathrm{mg} \mathrm{Cu} / \mathrm{kg}$ of dry matter in roots. In radishes from urban allotment gardens 2-14 $\mathrm{mg} \mathrm{Cu} / \mathrm{kg}$ of dry matter and $27-708 \mathrm{mg} \mathrm{Zn} / \mathrm{kg}$ of dry matter have been recorded. The leaves of radishes contained between 4 and $19 \mathrm{mg} \mathrm{Cu} / \mathrm{kg}$ of dry matter and between 35 and $470 \mathrm{mg} \mathrm{Zn/kg}$ of dry matter. Plants from uncontaminated areas typically have concentrations of copper ranging from 1 to $10 \mathrm{mg} / \mathrm{kg}$ of dry matter and concentration of zinc ranging from 12 to $47 \mathrm{mg} \mathrm{Zn/kg} \mathrm{of} \mathrm{dry} \mathrm{matter.}$ 
The overall content of copper in soils is significantly correlated with the content of zinc in soils, $r=0.5113$ (Fig. 6). The $r$ correlation coefficient between these metals in soils in the allotment gardens in Wrocław amounts to 0.89 [6], in soils adjacent to a petrol station in Cracow - 0.48 [8], in soils of the Jelenia Góra county - 0.50 [9], in the floodplains in Opole -0.7550 [19], in urban soils (Torino, Italy) -0.892 and in rural soils -0.330 [2]. In the case of plant material strong correlation between zinc and copper has been observed, which may indicate the same location of their origin $(r=0.7332)$. The content of copper in soils and grasses indicates medium strength of the linear correlation, $r=0.6278$ and weak correlation for zinc, $r=0.2677$ (Fig. 7).
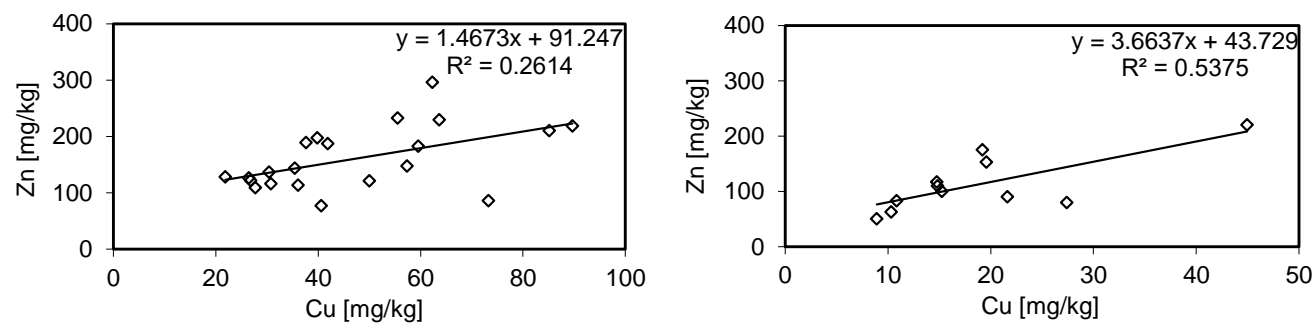

Fig. 6. Dependences of $\mathrm{Zn}$ contents on $\mathrm{Cu}$ contents in soils (left) and grasses (right)
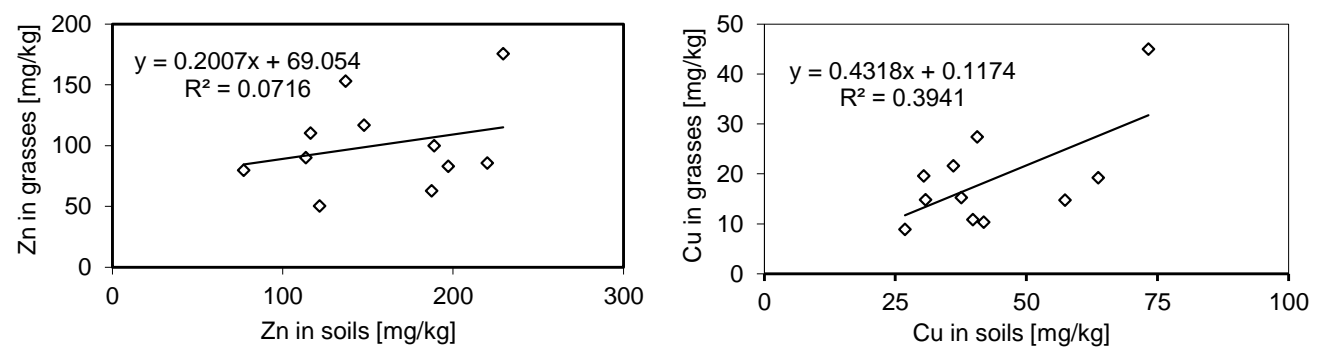

Fig. 7. Dependences of metal contents in grasses on metal contents in soils for $\mathrm{Zn}$ (left) and $\mathrm{Cu}$ (right)

With the assumed significance level of $p=0.05$, Pearson's $r$ correlation coefficient designates statistically significant relationships $\mathrm{Zn}$ in soil/ $\mathrm{Cu}$ in soil (Fig. 6), $\mathrm{Zn}$ in grass/Cu in grass (Fig. 6) and $\mathrm{Cu}$ in grass/Cu in soil (Fig. 7). In these three cases correlations are statistically significant, while the correlation $\mathrm{Zn}$ in soil/Zn in grasses (Fig. 7) is statistically insignificant. Cook et al. [20] present the correlation between the content of the same metal in soil and plant, divided into leaves and roots. For copper the $r$ correlation coefficient in Taraxacum spp. amounts to 0.736 in roots and 0.842 in leaves. The $r$ correlation coefficient for zinc in roots of dandelion amounts to 0.487 and 0.281 in leaves of the plant. 


\section{CONCLUSIONS}

- There are significant differences in the content of metals in urban soils in various locations, which stem from the distribution of contaminants in relations to the intensity of traffic. Average concentration of metal in soils equals $156.61 \mathrm{mg} \mathrm{Zn} / \mathrm{kg}$ of dry matter and $46.88 \mathrm{mg} \mathrm{Cu} / \mathrm{kg}$ of dry matter.

- The index of the enrichment of soils in zinc and copper in relation to the natural levels of these metals in uncontaminated soils amounts to 5.22 for zinc and 9.44 for copper.

- The exceeding of the permissible values of both metals $(300 \mathrm{mg} \mathrm{Zn} / \mathrm{kg}$ of dry matter and $150 \mathrm{mg} \mathrm{Cu} / \mathrm{kg}$ of dry matter) in type B soils, which include, among others, urbanized and built-up areas have not been recorded.

- The average concentration of zinc and copper in grasses amounts $101.50 \mathrm{mg} \mathrm{Zn} / \mathrm{kg}$ of dry matter and $16.28 \mathrm{mg} \mathrm{Cu} / \mathrm{kg}$ of dry matter, respectively. In both cases, the values are higher than the concentrations of these metals in plants from the uncontaminated areas (12-47 $\mathrm{mg} \mathrm{Zn} / \mathrm{kg}$ of dry matter and $1-10 \mathrm{mg} \mathrm{Cu} / \mathrm{kg}$ of dry matter).

- The bioaccumulation coefficients, on average 0.71 for zinc and 0.42 for copper, indicate the ease of accumulation of these metals in plants.

- The copper and zinc contents in grasses are strongly correlated with itself $(r=0.7332)$, which may indicate the same location of origin of both metals. In the case of soils, the correlation coefficient equals 0.5113 .

\section{REFERENCES}

[1] Mazur K., GondeK K., FilipeK-MAZur B., Heavy metal contents in soils and plants from areas localized along the No. 4 Road within the boundaries of the country of Ropczyce-Sędziszów. Part 1. Physico-chemical properties of soils and total heavy metal content, Ecol. Chem. Eng., 2007, 14 (5-6), 487.

[2] BIASIOLI M., BARBERIS R., AJMONE-MARSAN F., The influence of a large city on some soil properties and metal content, Sci. Total Environ., 2006, 356, 154.

[3] SAMEK L., ZwoźDZIAK A., SÓwKA I., Chemical characterization and source identification of particulate master PM10 in a rural and urban sites in Poland, Environ. Protect. Eng., 2013, 39 (4), 91.

[4] Sówka I., Zwoździak A., Trzepla-Nabaglo K., Skrętowicz M., ZwoźdZiaK J., PM2,5 elemental composition and source apportionment in a residential area of Wrocław, Poland, Environ. Protect. Eng., 2012, 38 (1), 73.

[5] Mundala P., Szmalec A., Petryk A., Trace element contents in topsoil located near steel plant in Krakow-Nowa Huta, Ecol. Eng., 2013, 33, 67.

[6] Kabala C., Chodak T., Szerszeń L., Karczewska A., Szopka K., Fratczuk U., Factors influencing the concentration of heavy metals in soils of allotment gardens in the city of Wroctaw, Poland, Fresenius Environ. Bull., 2009, 18 (7), 1118.

[7] Madrid L., Diaz-Barrientos E., Ruiz-Cortes E., Reinoso R., Biasioli M., Davidson C.M., Duarte A.C., GrČman H., Hossak I., Hursthouse A.S., Kralu T., Ljung K., Otabbong E., Rodrigues S., URGUHART G.J., AJMONE-MARSAN F., Variability in concentrations of potentially toxic elements in urban parks from six European cities, J. Environ. Monit., 2006, 8, 1158. 
[8] BARAN A., SPALEK I., JASIEWICZ C., The content of heavy metals in plants and soils adjacent to the selected petrol oil stations in Cracow, The 2nd Cracow Conference of Young Scientists, Cracow 2007, 265.

[9] KASZUBKIEWICZ J., KAWAŁKO D., The content of selected heavy metals in soils and plants in the Jelenia Góra county, Environ. Prot. Natural Res. (ENVIRON.), 2009, 40, 177.

[10] AleKSANDER-KwatercZaK U., RAJCA A., Urban soil contamination with lead and cadmium in the playgrounds located near busy streets in Cracow (South Poland), Geology, Geophysics, Environ (GGE), 2015, 41 (1), 7.

[11] Dziubanek G., Baranowska R., Oleksiak K., Heavy metals in the soils of Upper Silesia. A problem from the past or a present hazard?, J. Ecol. Health, 2012, 16 (4), 169.

[12] Report on the state of the environment in the Lower Silesia in 2014 (http://www.wroclaw.pios.gov.pl).

[13] Tomassi-Morawiec H., Lis J., Pasieczna A., Geochemical Mapping of Poland. Geochemical Atlas of Wroctaw and Its Environs. Part I, Polish Geological Institute, National Research Institute, Warsaw 1998 (www.mapgeochem.pgi.gov.pl).

[14] Lis J., Pasieczna A., Mojski J.E., PrzeniosŁo S., Sylwestrzak H., Strzelecki R., WoŁkowicz S., Geochemical Atlas of Poland, A. Pasieczna (Ed.), 2012 (changed and supplemented online version of the 1995 publication, http://www.mapgeochem.pgi.gov.pl/poland/atlas.html).

[15] Kabata-Pendias A., Piotrowska M., Basis for the assessment of chemical contamination of soils. Heavy metals, sulfur and PAH, Environmental Monitoring Library, PIOŚ, IUNG, Warszawa 1995, 28.

[16] Regulation of September 9th 2002 by the Minister of Environment on soil quality standards and ground quality standards, Journal of Laws, 2002, No. 165, pos. 1359.

[17] GREINERT A., Selected heavy metals and their behavior in urban soils versus soil quality standards, Environ. Protect. Eng., 2010, 36 (1), 45.

[18] Kabata-Pendias A., Pendias H., Trace elements in soil and plants, CRC Press, Inc., USA, 2011.

[19] PISAREK I., Anthropogenic enrichment of soils with heavy metals in the flooded area in the Opole city region, Ann. Set Environ. Protect., 2008, 10, 645.

[20] СоoK C.M., SGardeli S.P., Pantis J.D., Lanaras T., Concentrations of Pb, Zn, and Cu in Taraxacum spp. in relation to urban pollution, Bull. Environ. Contam. Toxicol., 1994, 53, 204. 